\title{
PENGEMBANGAN KELEMBAGAAN PENGGUNAAN LAHAN DI DAS CATUR KABUPATEN MADIUN
}

\author{
Development of Land Use Institution in Catur Watershed Madiun
}

\author{
Khabibi Nurrofi' Pratama ${ }^{1}$, Kukuh Murtilaksono ${ }^{2}$ and Hendrayanto ${ }^{3}$
}

Diterima: 30 Maret 2017

Disetujui: 31 Mei 2017

\begin{abstract}
Abstrak: Penggunaan lahan yang melebihi kemampuannya menyebabkan kekritisan DAS. Hal ini diduga akibat kurangnya koordinasi dalam perumusan dan pelaksanaan kelembagaan penggunaan lahan dalam pengelolaan DAS. DAS Catur adalah salah satu DAS kritis di Indonesia. Penelitian ini bertujuan untuk merumuskan strategi pengembangan kelembagaan penggunaan lahan di DAS Catur. Kerangka kerja analisis dan pengembangan kelembagaan (IAD) digunakan untuk merumuskan strategi pengembangan kelembagaan. Hasil penelitian menunjukkan masalah penggunaan lahan dalam mengelola DAS Catur meliputi 1) tumpang tindih dalam penetapan fungsi kawasan, 2) kurangnya sosialisasi dan pengawasan dalam pelaksanaan peraturan, dan 3) forum koordinasi yang belum efektif dalam mengakomodasi kepentingan masing-masing aktor. Oleh karena itu, perlu identifikasi dan keterlibatan semua aktor dalam musyawarah perencanaan pembangunan (Musrenbang) untuk mendapatkan rencana pembangunan yang berorientasi pada pencapaian tujuan bersama.
\end{abstract}

Kata Kunci: penggunaan lahan, kelembagaan, DAS, Koordinasi

Abstract: Land use over its capability led to a watershed criticality. It was hypothesized by a lack of coordination in formulation and implementation of land use institution in watershed management. Catur watershed is one of critical watershed in Indonesia. This study aimed to formulate the development strategies of land use institution in Catur watershed. Institution analysis and development (IAD) framework was used to formulate it. The results showed land use problems in managing Catur watershed were 1) the overlap in determination of area function, 2) lack of socialization and supervision in implementing the regulation, and 3) a forum of coordination that has not been effective in accommodating the interests of each actors. Therefore, need an identification and involvement all the actors on conference of development planning (Musrenbang) to achieve a good governance.

Keywords: land use, institution, watershed, coordination

\section{PENDAHULUAN}

Sebanyak 108 Daerah Aliran Sungai (DAS) di Indonesia dalam keadaaan kritis/rusak (Ditjen PDASHL, 2015). Kerusakan DAS dicirikan dengan luasnya lahan kritis yang menyebabkan fungsi DAS dalam tata air tidak optimal sehingga frekuensi dan besaran

1 Program Studi Ilmu Pengelolaan DAS. Sekolah Pascasarjana Institut Pertanian Bogor

2 Departemen Ilmu Tanah dan Sumberdaya Lahan. Fakultas Pertanian. Institut Pertanian Bogor

3 Departemen Manajeman Hutan. Fakultas Kehutanan. Institut Pertanian Bogor

Correspondence: khabibi.forester@gmail.com 
banjir dan kekeringan semakin meningkat (Arsyad, 2010; Rosyidie, 2013; Halim, 2014; Permatasari et al., 2017). Bedasarkan sudut pandang kelembagaan, kondisi ini disebabkan oleh lemahnya koordinasi antar aktor dalam pengelolaan DAS. Lemahnya koordinasi antar aktor menyebabkan program dan kegiatan belum berorientasi pada pencapaian tujuan bersama pengelolaan DAS. Program kerja disusun secara parsial berdasarkan kepentingan masing-masing aktor dan tidak jarang terjadi tumpang-tindih sehingga pengelolaan DAS tidak efektif (Asdak, 2010). Tumpang-tindih kepentingan terjadi karena masing-masing aktor berupaya mendapatkan keuntungan sebesar-besarnya, sesuai teori ekonomi neoklasik. Teori ekonomi neoklasik mengasumsikan bahwa tiap individu berpikir rasional dalam bertindak serta bersikap individualistik untuk mendapatkan keuntungan yang sebesar-besarnya (Kartodihardjo et al., 2004).

Pemerintah menyadari perlunya koordinasi antar aktor dalam penyelenggaraan pembangunan. Hal ini tersurat dalam Sistem Perencanaan Pembangunan Nasional (Undang-Undang (UU) Nomor 25 Tahun 2004). UU tersebut mengatur penyusunan rencana pembangunan jangka panjang (RPJP), jangka menengah (RPJM) serta tahunan (RKP) tingkat nasional dan daerah. Penyusunan RPJP tingkat nasional dan daerah berpedoman pada rencana tata ruang dan wilayah (RTRW) (UU Nomor 26 Tahun 2007) serta kajian lingkungan hidup strategis (KLHS) (UU Nomor 32 Tahun 2009) untuk mewujudkan ruang wilayah yang aman, nyaman, produktif dan berkelanjutan. Lembaga koordinatif perencanaan pembangunan nasional dan daerah adalah musyawarah rencana pembangunan (Musrenbang), yang dikoordinasikan oleh Kepala Badan Perencanaan Pembangunan Nasional/Daerah (Bappenas/Bappeda) dengan melibatkan seluruh aktor pembangunan.

Penyusunan rencana pembangunan diselenggarakan berdasarkan unit administrasi pemerintahan (nasional, provinsi dan kabupaten). Hal ini oleh beberapa aktor dipandang tidak berdasarkan pada unit ecology (ekosistem). Dalam kerangka pendekatan perencanaan pembangunan menggunakan unit ekologi, muncul perencanaan pembangunan menggunakan unit Wilayah Sungai (UU No 7/2004), Ekoregion (UU No 32/2009) dan DAS (PP 37/2012). Produk perencanaan tersebut berupa RPPLH, Rencana Pengelolaan DAS (terpadu) dan lainnya yang seringkali tidak singkron dengan rencana pembangunan wilayah (RPJP, RPJM dan RKP). Sementara itu, penganggaran pembangunan nasional maupun daerah mengacu pada rencana pembangunan wilayah.

DAS Catur seluas 18.457,52 Ha hampir seluruhnya merupakan wilayah administrasi pemerintahan Kabupaten Madiun (Kemenhut, 2009). Kerusakan fungsi DAS Catur dicirikan oleh berbagai kejadian bencana seperti tanah longsor, banjir bandang dan kekeringan yang terjadi (BPBD Kabupaten Madiun, 2015). Kerusakan DAS disebabkan oleh penggunaan lahan yang melebihi kemampuannya (Sunarti et al., 2008; Rosyidie, 2013; Suyana dan Muliawati, 2014). Kondisi demikian diduga akibat lemahnya koordinasi dalam perumusan dan implementasi kelembagaan penggunaan lahan di DAS Catur.

Kelembagaan ditetapkan untuk mengarahkan perilaku individu dan masyarakat agar sejalan dengan tujuan publik yang telah ditetapkan (Kartodihardjo et al., 2004). Kelembagaan penggunaan lahan di DAS Catur perlu dikaji untuk memperoleh informasi terkait masalah kelembagaan. Masalah kelembagaan merupakan dasar untuk merumuskan strategi pengembangan kelembagaan penggunaan lahan yang lebih efektif bagi pemulihan fungsi DAS Catur. Salah satu metode dalam analisis kelembagaan pengelolaan DAS yaitu menggunakan kerangka kerja institution analysis and development (IAD) sebagaimana Gambar 1. Kerangka kerja IAD merupakan metode untuk menganalisis dan menguji hipotesis tentang perilaku dari situasi yang beragam di berbagai tingkat analisis tentang bagaimana aturan, kondisi fisik dan atribut masyarakat memengaruhi struktur arena aksi, pola interaksi dan hasil (Ostrom 2010). Penelitian ini bertujuan untuk mendapatkan rumusan pengembangan kelembagaan penggunaan lahan di DAS Catur. Kajian 
kelembagaan dalam penelitian ini dibatasi pada kelembagaan penetapan status dan fungsi kawasan berdasarkan rencana tata ruang wilayah (RTRW) dan Penetapan Kawasan Hutan oleh Menteri Lingkungan Hidup dan Kehutanan.

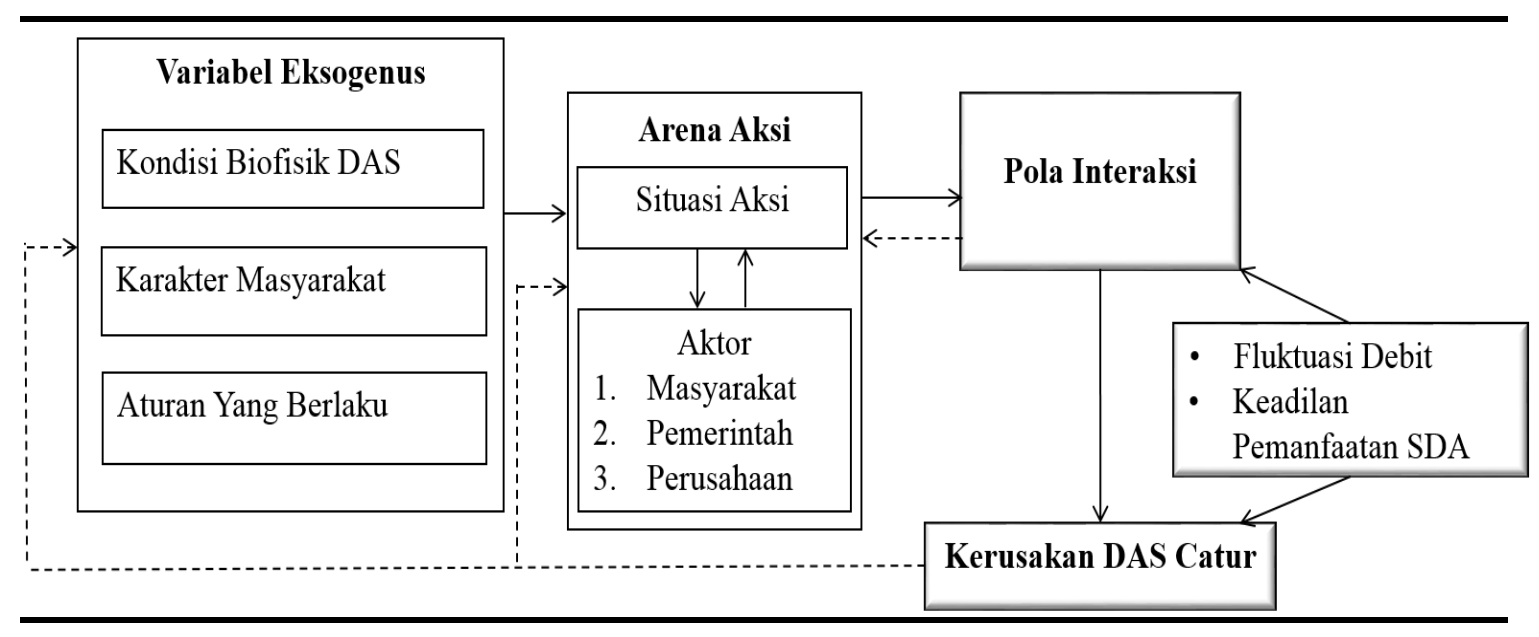

Gambar 1. Bagan Alir Kerangka Pemikiran

\section{METODE PENELITIAN}

\section{Lokasi dan Waktu Penelitian}

Penelitian dilakukan di DAS Catur, yang merupakan Sub-DAS Kali Madiun, DAS Solo. Secara administrasi pemerintah, mayoritas DAS Catur merupakan wilayah Kabupaten Madiun (Gambar 2). Pengumpulan data dilaksanakan pada bulan Maret hingga Agustus 2016, sedangkan pengolahan dan analisis data dilakukan pada bulan September 2016 hingga Februari 2017.

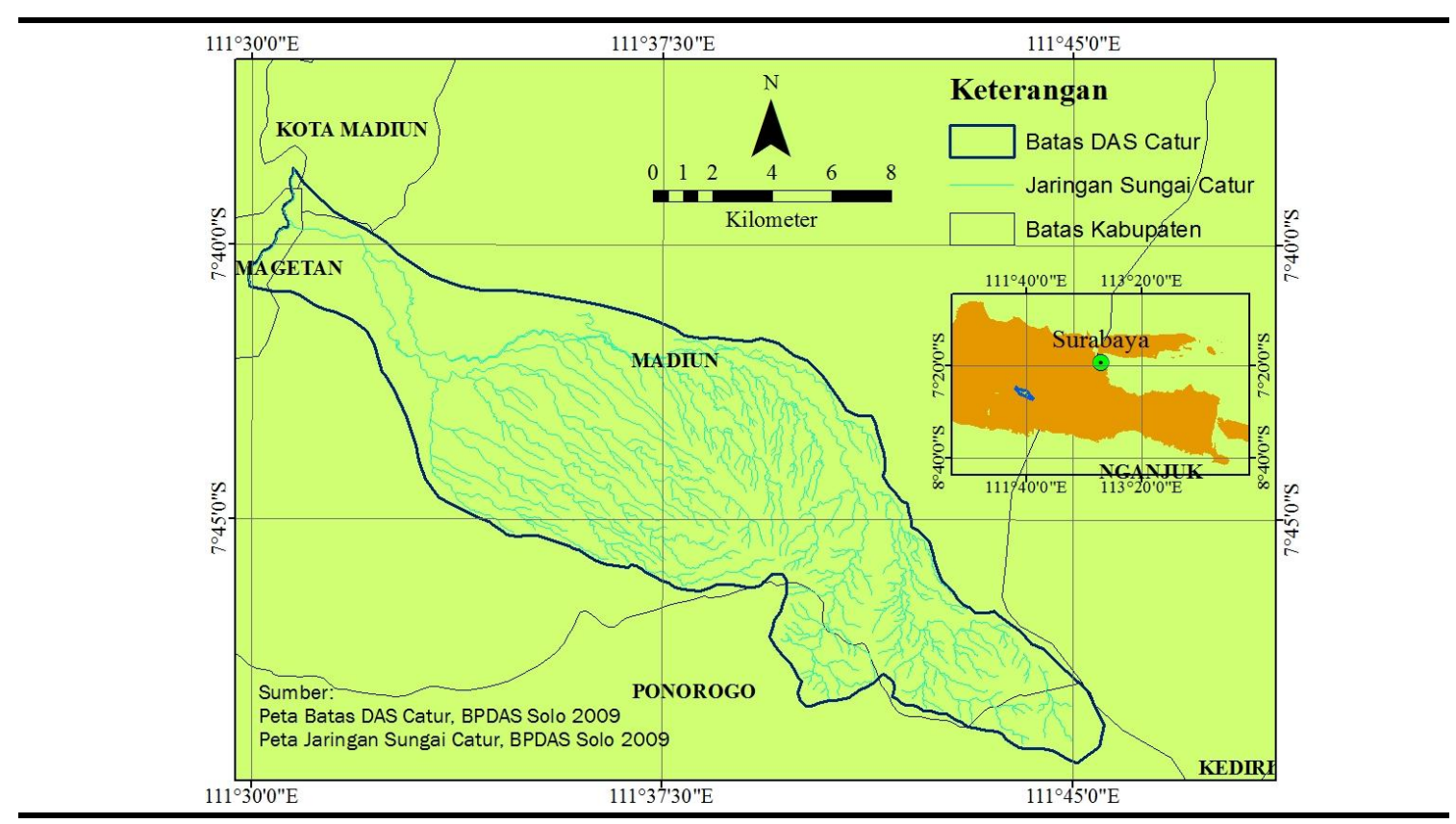

Gambar 2. Peta Batas DAS Catur Kabupaten Madiun 


\section{Jenis dan Sumber Data} Tabel 1.

Jenis data yang digunakan dalam penelitian dan sumberdatanya disajikan dalam Tabel 1 Jenis, sumber dan analisis data yang dilakukan dalam penelitian

\begin{tabular}{|c|c|c|c|}
\hline Tujuan & Data & Sumber data & Analisis data \\
\hline $\begin{array}{l}\text { Menganalisis karakteristik } \\
\text { biofisik, atribut sosial dan } \\
\text { ekonomi serta aturan yang } \\
\text { berlaku di DAS Catur }\end{array}$ & $\begin{array}{l}\text { Curah hujan, } \\
\text { karakteristik DAS, } \\
\text { demografi dan } \\
\text { kepemilikan lahan } \\
\text { serta peraturan } \\
\text { yang berlaku }\end{array}$ & $\begin{array}{l}\text { Ketua dan anggota kelompok } \\
\text { tani; BPDAS Solo; BPSDA Jawa } \\
\text { Timur; Dinas PU Pengairan, } \\
\text { Dishutbun, Bappeda, Diperta dan } \\
\text { BKP Kabupaten Madiun; Perum } \\
\text { Perhutani KPH Madiun dan } \\
\text { Lawu Ds; serta PT Perkebunan } \\
\text { Kandangan }\end{array}$ & $\begin{array}{l}\text { Analisis } \\
\text { kemampuan lahan, } \\
\text { analisis karakter } \\
\text { komunitas dan } \\
\text { analisis isi }\end{array}$ \\
\hline $\begin{array}{l}\text { Menganalisis struktur arena } \\
\text { aksi dan pola interaksi di } \\
\text { DAS Catur }\end{array}$ & $\begin{array}{l}\text { Aktor yang } \\
\text { terlibat dan upaya } \\
\text { yang mereka } \\
\text { tempuh dalam } \\
\text { pengelolaan DAS }\end{array}$ & $\begin{array}{l}\text { Ketua dan anggota kelompok } \\
\text { tani; BPDAS Solo; BPSDA Jawa } \\
\text { Timur; Dinas PU Pengairan, } \\
\text { Dishutbun, Bappeda, Diperta dan } \\
\text { BKP Kabupaten Madiun; Perum } \\
\text { Perhutani KPH Madiun dan } \\
\text { Lawu Ds; serta PT Perkebunan } \\
\text { Kandangan }\end{array}$ & IAD \\
\hline $\begin{array}{l}\text { Menganalisis strategi } \\
\text { pengembangan } \\
\text { kelembagaan }\end{array}$ & $\begin{array}{l}\text { Hasil analisis poin } \\
1 \text { dan } 2\end{array}$ & Hasil analisis poin 1 dan 2 & IAD \\
\hline
\end{tabular}

Data didapat melalui observasi dan wawancara tidak terstruktur. Penentuan informan kunci dalam wawancara didasarkan pada purposive sampling atas dasar pimpinan di instansi terkait pengelolaan DAS Catur serta dikembangkan dengan snowball sampling. Wawancara dilakukan kepada 52 informan yang terdiri dari 22 informan dari kalangan pemerintahan, 17 informan dari kalangan petani/masyarakat dan 12 informan dari karyawan BUMN/S. Untuk melengkapi dan memverifikasi hasil wawancara dilakukan observasi lapang dan studi literatur berbagai dokumen terkait pengelolaan DAS Catur.

\section{Analisis Kemampuan dan Kerusakan Lahan}

Analisis kemampuan lahan didasarkan jenis tanah, kemiringan lereng dan curah hujan wilayah DAS Catur. Klasifikasi kemampuan lahan mengacu pada sistem klasifikasi yang dikemukakan oleh Hockensmith dan Steele (1943) serta Klingebiel dan Montgomery (1973) (Arsyad, 2010). Analisis kerusakan lahan dilakukan dengan menilai kesesuaian penggunaan lahan dengan kelas kemampuan lahannya. Penggunaan lahan didapat dari hasil interpretasi Citra Quick Bird yang diunduh dari google earth @2016 (pengambilan citra mayoritas dilakkukan pada 1 Februari 2016 dan 28 Agustus 2015).

\section{Analisis Karakteristik Komunitas}

Analisis karakter komunitas ditujukan untuk mengetahui seberapa banyak kelompokkelompok yang berkepentingan terhadap penggunaan lahan serta hubungan antar kelompok tersebut. Analisis deskriptif dilakukan dari hasil studi literatur, wawancara dan observasi yang dilakukan di DAS Catur. Analisis kerakter komunitas DAS Catur dilakukan melalui pendekatan karakter komunitas di 4 kecamatan di Kabupaten Madiun yaitu Kecamatan Kare, Wungu, Dagangan dan Geger. 


\section{Analisis Isi}

Analisis isi (content analysis) terhadap peraturan yang berlaku bertujuan untuk mendapatkan informasi terkait dasar setiap aktor dalam menjelaskan dan membenarkan tindakannya dalam penggunaan lahan. Analisis isi terhadap peraturan yang berlaku didasarkan pada unsur-unsur struktur situasi aksi IAD, yaitu aktor yang terlibat, posisi, otoritas tindakan, agregasi, informasi, ruang lingkup dan biaya-manfaat (Ostrom 2005).

\section{Analisis Pengembangan Kelembagaan dengan Kerangka Kerja IAD}

Dalam analisis pengembangan kelembagaan, untuk mendapatkan hasil berupa pengelolaan DAS berkelanjutan dilakukan identifikasi terhadap kondisi biofisik, karakter sosial dan ekonomi serta aturan yang berlaku. Adapun langkah dalam proses analisisnya yang meliputi: 1) Menentukan tujuan analisis kelembagaan pengelolaan DAS Catur; 2) Menganalisis kondisi biofisik DAS Catur; 3) Menganalisis karakter sosial dan ekonomi di DAS Catur; 4) Menganalisis aturan yang berlaku di DAS Catur; 5) Menganalisis arena aksi dalam pengelolaan DAS Catur; 6) Menganalisis pola interaksi dalam pengelolaan DAS Catur; dan 7) Merumuskan kelembagaan untuk mencapai pengelolaan DAS Catur yang berkelanjutan (Ostrom dan Hess, 2007).

\section{HASIL DAN PEMBAHASAN}

\section{Kondisi Biofisik DAS Catur}

Berdasarkan hasil analisis didapatkan beberapa kelas kemampuan lahan di DAS Catur yaitu II, III, IV, VI, VII dan VIII. Kelas kemampuan lahan I tidak ada di DAS Catur karena iklim yang kering dengan curah hujan rata-rata $1.546,7 \mathrm{~mm} /$ tahun serta belum adanya waduk sebagai sumber air permukaan di musim kemarau. Luasan masing-masing kelas kemampuan lahan dan keterangan faktor penghambat serta sebaran kelas kemampuan lahan tersaji dalam Tabel 2 dan Gambar 3.

Tabel 2. Luasan dan faktor penghambat setiap kelas kemampuan lahan di DAS Catur

\begin{tabular}{|c|c|c|}
\hline $\begin{array}{c}\text { Kelas } \\
\text { kemampuan }\end{array}$ & Faktor pembatas dan penggunaan lahannya (Arsyad 2010) & Luas (Ha) \\
\hline II & $\begin{array}{l}\text { Kemiringan }>3 \% \text { - } 8 \% \text { dan keadaan iklim yang kurang mendukung kegiatan } \\
\text { pertanian secara intensif. Penggunaan lahan untuk persawahan, } \\
\text { ladang/kebun, permukiman, penggembalaan ternak dan hutan. }\end{array}$ & $4.225,92$ \\
\hline III & $\begin{array}{l}\text { Kemiringan }>8 \%-15 \% \text {, kepekaan tanah terhadap erosi agak tinggi sampai } \\
\text { tinggi dan hambatan iklim agak besar. Penggunaan lahan untuk persawahan, } \\
\text { ladang/kebun, permukiman, penggembalaan ternak dan hutan. }\end{array}$ & $3.592,25$ \\
\hline IV & $\begin{array}{l}\text { Kemiringan }>15 \% \text { - } 30 \% \text {, kepekaan tanah terhadap erosi sangat tinggi dan } \\
\text { keadaan iklim kurang menguntungkan. Penggunaan lahan untuk } \\
\text { ladang/kebun, penggembalaan ternak dan hutan. }\end{array}$ & $3.976,94$ \\
\hline VI & $\begin{array}{l}\text { Kemiringan }>30 \%-45 \% \text {, telah teresosi berat dan keadaan iklim yang tidak } \\
\text { sesuai. Penggunaan lahan untuk penggembalaan ternak dan hutan. }\end{array}$ & $2.982,24$ \\
\hline VII & $\begin{array}{l}\text { Kemiringan }>45 \% \text { - } 65 \% \text { dan terjadi erosi yang sangat berat berupa erosi } \\
\text { parit. Penggunaan lahan untuk penggembalaan ternak dan hutan. }\end{array}$ & $2.261,02$ \\
\hline VIII & $\begin{array}{l}\text { Kemiringan }>65 \%,>90 \% \text { permukaan lahan berbatu dan kapasitas menahan } \\
\text { air yang sangat rendah. Penggunaan lahan untuk hutan. }\end{array}$ & $1.419,15$ \\
\hline & Total & $18.457,52$ \\
\hline
\end{tabular}




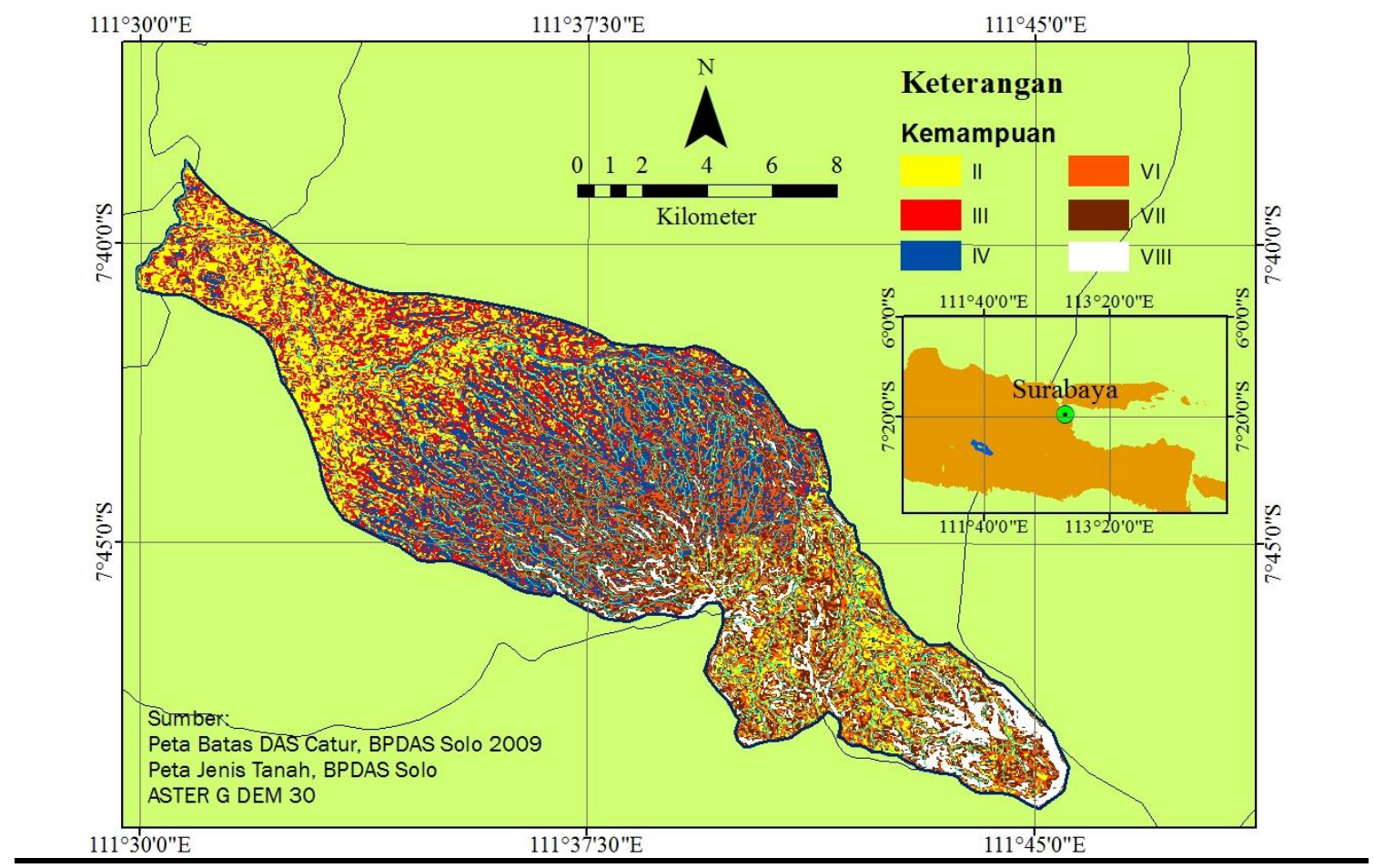

Gambar 3. Peta Sebaran Kelas Kemampuan Lahan di DAS Catur

Faktor penghambat domiman dalam penggunaan lahan di DAS Catur adalah kemiringan lereng $(>45 \%)$ dan tanah yang peka terhadap erosi dengan luas 6.530,57 Ha. Kondisi lahan yang miring dapat meningkatkan aliran permukaan sehingga daya rusak dan daya angkut air terhadap tanah meningkat (Harjianto et al., 2016). Penerapan KTA secara mekanik dan vegetatif perlu dilakukan untuk meningkatkan resapan air ke dalam tanah serta mengurangi daya rusak dan daya angkut air terhadap tanah (Saida et al., 2013; Maria dan Lestiana, 2014).

\section{Atribut Komunitas dalam Penggunaan Lahan di DAS Catur}

Karakter sosial dan ekonomi masyarakat yang memengaruhi terjadinya perubahan penggunaan lahan meliputi jumlah dan kepadatan penduduk, tingkat pendidikan masyarakat dan harga komoditas pertanian (Verbist et al., 2004; Sudirman et al., 2010; Kusrini et al., 2011). Jumlah penduduk di DAS Catur sebanyak 205.504 jiwa, dengan tingkat kepadatan penduduk mencapai 595 jiwa $/ \mathrm{km}^{2}$. Penduduk yang melanjutkan ke pendidikan tinggi hanya 7.146 orang $( \pm 3,5 \%)$. Masyarakat di DAS Catur mayoritas bekerja di sektor pertanian (Bappeda Kabupaten Madiun, 2015). Oleh sebab itu, sektor pertanian menjadi dasar pembangunan perekonomian yang tertuang melalui visi Kabupaten Madiun dalam RTRW tahun 2009-2029.

Dinamika penggunaan lahan juga sangat terkait dengan hak kepemilikian lahan (Murtilaksono 2013). Hak kepemilikan adalah hak yang dimiliki individu, masyarakat atau negara atas suatu sumberdaya/aset untuk mengelola, memanfaatkan, memindah tangankan bahkan merusaknya (Nursidah, 2012). Melalui hak kepemilikan lahan, seseorang/organisasi dapat menentukan bentuk penggunaan lahan yang dimilikinya. Terdapat dua jenis hak kepemilikan lahan di DAS Catur yaitu state property (milik negara) dan privat property (milik individu masyarakat). Lahan milik negara di DAS Catur berupa areal Hak Guna Usaha (SK No. 19/HGU/DA/1988) yang dikelola PT Perkebunan Kandangan dan kawasan hutan (SK Menhut Nomor SK.395/Menhut-II/2011) yang dikelola 
oleh Perum Perhutani. Pemanfaatan lahan di DAS Catur diatur oleh penyelenggara pemerintahan yang meliputi Bappeda, Diperta, BKP dan Dishutbun Kabupaten Madiun, Badan Pertanahan Negara (BPN) dan Kementerian Lingkungan Hidup dan Kehutanan (KLHK). Luasan masing-masing kepemilikan lahan di DAS Catur tersaji dalam Tabel 3.

\begin{tabular}{lr}
\multicolumn{2}{c}{ Tabel 3 Luasan masing-masing kepemilikan lahan di DAS Catur } \\
\hline \multicolumn{1}{c}{ Kepemilikan Lahan } & \multicolumn{1}{c}{ Luas (Ha) } \\
\hline Milik-Masyarakat & $8.502,23$ \\
Negara-Perhutani & $8.003,34$ \\
Negara-Perkebunan & $1.951,96$ \\
Total & $18.457,52$ \\
\hline
\end{tabular}

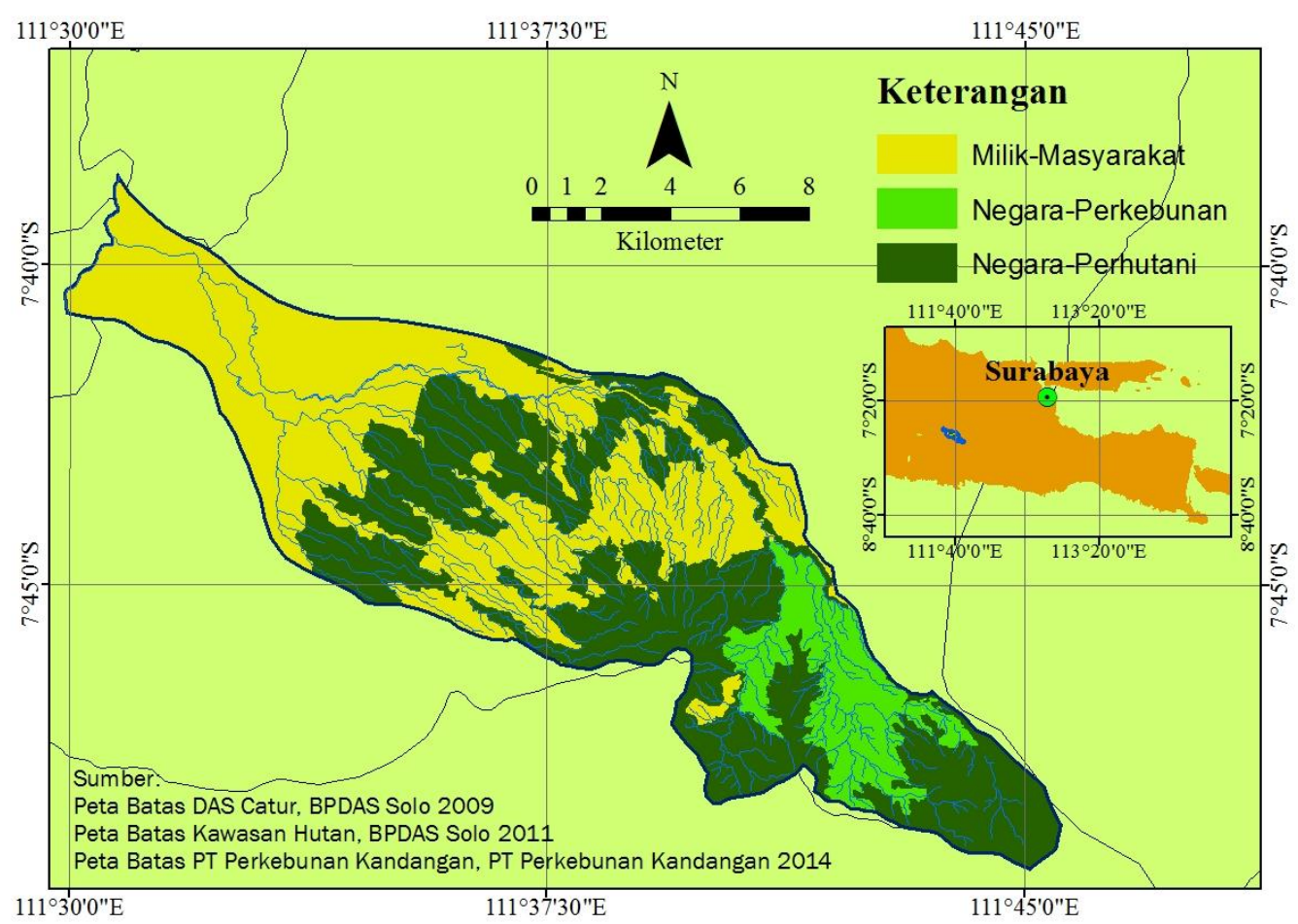

Gambar 4. Peta Sebaran Kepemilikan Lahan di DAS Catur

\section{Aturan yang Berlaku dalam Penggunaan Lahan di DAS Catur}

Aturan yang dikaji dalam penelitian yaitu UU Nomor 26 Tahun 2007 Tentang Penataan Ruang dan UU Nomor 41 Tahun 1999 Tentang Kehutanan beserta turunannya. Berdasarkan UU Penataan Ruang, fungsi suatu kawasan dituangkan dalam pola ruang yang termuat dalam RTRW. Penyusunan dan penetapan RTRW kabupaten diatur melalui PP Nomor 15 Tahun 2010 Tentang Penyelenggaraan Penataan Ruang. Ketentuan lebih lanjut terkait pedoman penyusunan RTRW Kabupaten Permen PU Nomor 16/PRT/M/2009. Berdasarkan UU Kehutanan, fungsi kawasan ditetapkan setelah dilakukan pengukuhan kawasan hutan. Mekanisme penetapan fungsi kawasan hutan secara rinci diatur melalui PP Nomor 44 Tahun 2004 Tentang Perencanaan Kehutanan. Ketentuan lebih lanjut mengenai kriteria dan tata cara penetapan fungsi hutan sebagai hutan lindung dan hutan produksi 
masing-masing diatur melalui SK Menteri Pertanian (Mentan) Nomor 837/Kpts/Um/11/1980 dan Nomor 683/Kpts/Um/8/1981.

Penetapan fungsi kawasan berdasarkan peraturan penataan ruang dan kehutanan memengaruhi tindakan aktor dalam penggunaan lahan di DAS Catur. Secara ringkas ulasan analisis isi peraturan penataan ruang dan kehutanan terkait penggunaan lahan di DAS Catur tersaji dalam Tabel 4. Uraian pada Tabel 4 menujukkan terdapat perbedaan isi antara peraturan dalam penataan ruang dan kehutanan ditijau dari struktur situasi aksi. Namun demikian untuk meminimalisir tumpang tindih dalam penetapan fungsi kawasan, diselenggarakan paduserasi antara tata guna hutan kesepakatan (TGHK) dengan RTRW di tingkat provinsi. Paduserasi TGHK dan RTRW di tingkat provinsi ini menjadi acuan penetapan fungsi kawasan dalam penyusunan RTRW Kabupaten Madiun Tahun 2011 dan SK Menteri LHK tentang penunjukan kawasan hutan Provinsi Jawa Timur tahun 2011.

Tabel 4 Analisis isi berdasarkan variabel situasi aksi (Ostrom 2005)

\begin{tabular}{|c|c|c|}
\hline $\begin{array}{c}\text { Variabel } \\
\text { situasi aksi }\end{array}$ & Penataan ruang (RTRW kabupaten) & Kehutanan (SK Menteri LHK) \\
\hline Aktor & $\begin{array}{l}\text { - Menteri Agraria dan Tata Ruang (Menteri ATR), } \\
\text { Gubernur, Bupati, DPRD Kabupaten dan } \\
\text { Masyarakat/Korporasi }\end{array}$ & $\begin{array}{l}\text { - Menteri Lingkungan Hidup dan } \\
\text { Kehutanan (LHK) dan } \\
\text { Masyarakat/Korporasi }\end{array}$ \\
\hline Posisi & $\begin{array}{l}\text { - Menteri ATR, Gubernur dan DPRD Kabupaten: } \\
\text { pengkaji RTRW Kabupaten } \\
\text { - Bupati: penyelenggara penataan ruang tingkat } \\
\text { kabupaten } \\
\text { - Masyarakat/Korporasi: pemanfaat ruang }\end{array}$ & $\begin{array}{l}\text { - Menteri LHK: penyelenggara bidang } \\
\text { kehutanan } \\
\text { - Masyarakat/Korporasi: pemanfaat } \\
\text { sumberdaya hutan }\end{array}$ \\
\hline Otoritas & $\begin{array}{l}\text { - Menteri ATR, Gubernur dan DPRD Kabupaten: } \\
\text { mengkaji rancangan RTRW kabupaten sesuai } \\
\text { kewenangannya } \\
\text { - Bupati: menyusun, menetapkan dan } \\
\text { mensosialisasikan RTRW kabupaten } \\
\text { - Masyarakat/Korporasi: dilibatkan dalam } \\
\text { penyusunan RTRW kabupaten. }\end{array}$ & $\begin{array}{l}\text { - Menteri LHK: menetapkan fungsi } \\
\text { kawasan hutan } \\
\text { - Masyarakat/Korporasi: memanfaatkan } \\
\text { kawasan hutan sesuai fungsi kawasan } \\
\text { dan izin pemanfaatannya }\end{array}$ \\
\hline Agregasi & $\begin{array}{l}\text { - Penyusunan RTRW kabupaten dilakukan Bupati } \\
\text { dan melibatkan masyarakat/korporasi } \\
\text { - RTRW kabupaten ditetapkan oleh bupati atas } \\
\text { persetujuan DPRD Kabupaten, Gubernur dan } \\
\text { Menteri ATR }\end{array}$ & $\begin{array}{l}\text { - Penetapan fungsi terhadap kawasan } \\
\text { hutan (setelah dilakukan pengukuhan } \\
\text { kawasan hutan) dilakukan oleh LHK }\end{array}$ \\
\hline Informasi & $\begin{array}{l}\text { - Penyusunan RTRW kabupaten mengacu RTRW } \\
\text { nasional dan provinsi, pedoman penyusunan } \\
\text { RTRW kabupaten dan RPJP kabupaten } \\
\text { - Pemerintah, pemerintah daerah dan } \\
\text { masyarakat/korporasi melakukan pengawasan } \\
\text { terhadap penyelenggaraan RTRW kabupaten }\end{array}$ & $\begin{array}{l}\text { - Penetapan fungsi kawasan hutan } \\
\text { mengacu kriteria hutan lindung dan } \\
\text { hutan produksi } \\
\text { - Pemerintah, pemerintah daerah dan } \\
\text { masyarakat/korporasi melakukan } \\
\text { pengawasan terhadap } \\
\text { penyelenggaraan kehutanan }\end{array}$ \\
\hline Lingkup & $\begin{array}{l}\text { - RTRW meliputi ruang darat, laut dan udara } \\
\text { serta ruang di dalam bumi }\end{array}$ & $\begin{array}{l}\text { - Penetapan fungsi kawasan berlaku di } \\
\text { dalam kawasan hutan }\end{array}$ \\
\hline $\begin{array}{l}\text { Biaya- } \\
\text { manfaat }\end{array}$ & $\begin{array}{l}\text { - RTRW kabupaten menjadi salah satu acuan } \\
\text { RPJP kabupaten yang dibiayai APBD } \\
\text { - Pemberian insentif dan disinsentif berupa pajak, } \\
\text { pembangunan infrastruktur, perizinan serta } \\
\text { penghargaan/sanksi pidana }\end{array}$ & - Tidak diatur \\
\hline
\end{tabular}

\section{Arena Aksi dalam Penggunaan Lahan di DAS Catur}

Hasil analisis kemampuan lahan dan penggunaan lahan menunjukkan bahwa terdapat penggunaan lahan seluas $2349.13 \mathrm{Ha}$ (12.72 \% dari total luas DAS Catur) tidak 
sesuai dengan kelas kemampuan lahannya, yang dimaknai sebagi kerusakan lahan (Tabel 5 dan Gambar 6). Kerusakan lahan sebagian besar (1 856.95 Ha sekitar 79\%) disebabkan oleh kegiatan pertanian baik pertanian lahan kering maupun pertanian lahan basah di kelas kemampuan lahan VI hingga VIII. Kerusakan lahan di DAS Catur juga terjadi akibat pembangunan permukiman di kelas kemampuan lahan IV sampai VIII yang mencapai $419.84 \mathrm{Ha}(18 \%)$. Penggunaan lahan tersebut merupakan faktor yang meningkatkan aliran yang memengaruhi debit air di Sungai Catur. Hasil pemantauan debit Sungai Catur oleh Balai Pengelolaan Sumberdaya Air (BPSDA) Provinsi Jawa Timur menunjukkan bahwa terjadi peningkatan koefisien regim sungai (perbandingan debit maksimum dan minimum) dari 11.1 pada tahun 2011 menjadi 123.4 pada tahun 2015. Kondisi ini memengaruhi berbagai kegiatan produksi yang memanfaatkan air permukaan di Sungai Catur terutama pada musim kemarau.

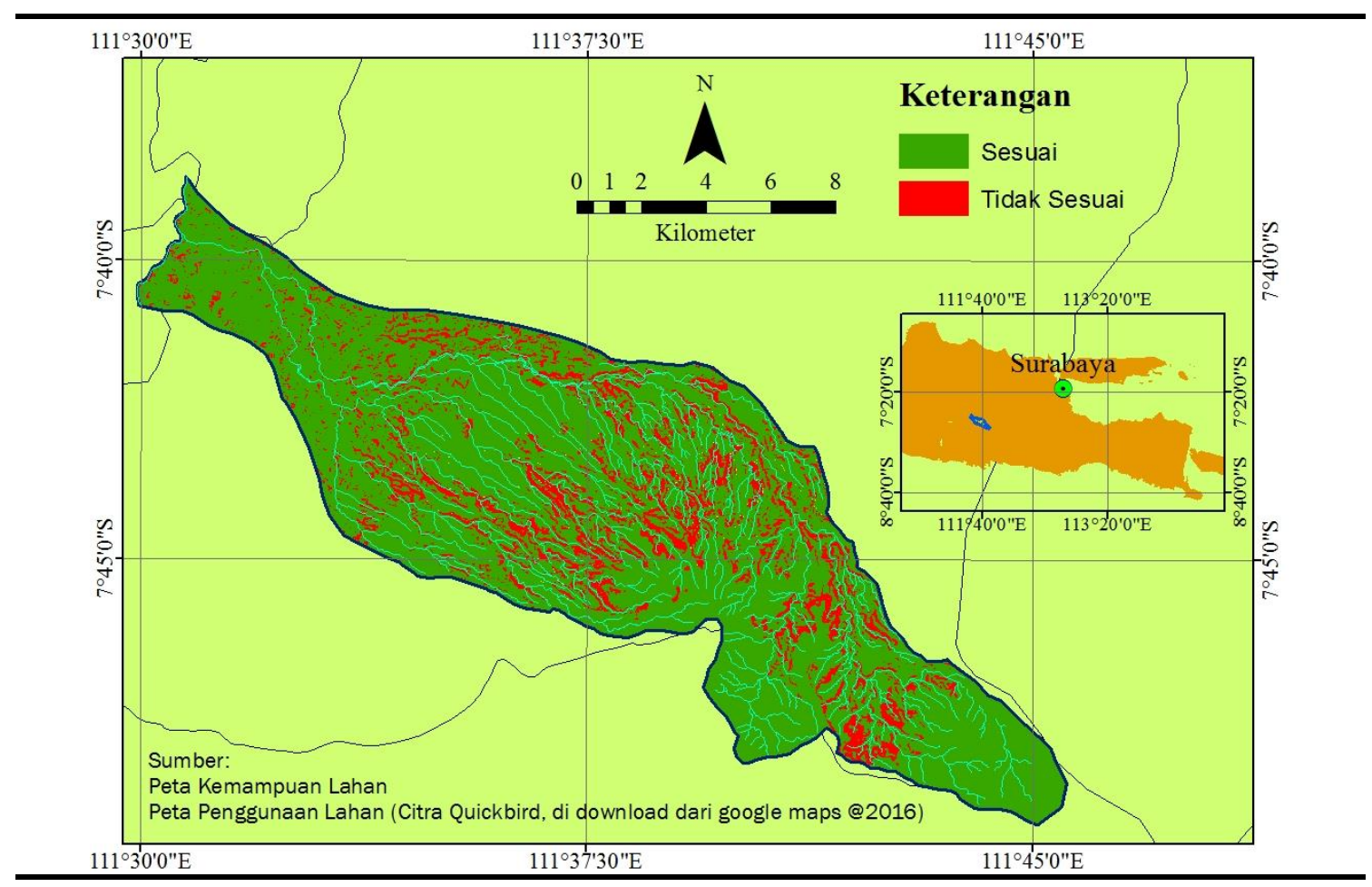

Gambar 4. Peta Sebaran Kepemilikan Lahan di DAS Catur

Hasil wawancara dengan pemanfaat air Sungai Catur (Himpunan Petani Pemakai Air/Hippa, Perum Jasa Tirta I, Pabrik Gula Kanigoro dan Pagotan, PDAM Kabupaten Madiun serta PLTA Golang dan Giringan) menyatakan bahwa ketika musim kemarau terjadi krisis air di Sungai Catur yang menghambat kegiatan produksi. Kondisi inilah yang kemudian mendorong para pemanfaat air (terutama petani) di DAS Catur mengeksploitasi air bawah tanah secara berlebihan menggunakan sumur bor. Hasil wawancara terhadap staf Bidang Program dan Laporan Dinas Pertanian (Diperta) Kabupaten Madiun dan Ketua Gapoktan Kecamatan Geger menyebutkan bahwa saat ini jumlah dan kedalaman sumur bor terus bertambah. Dikawatirkan hal ini akan berdampak habisnya stok air bawah tanah dan konflik sosial dalam pemanfaatan air di DAS Catur. Dalam mengantisipasi hal tersebut, Diperta dan Badan Ketahanan Pangan (BKP) Kabupaten Madiun telah berupaya memberikan penyuluhan dan himbauan untuk tidak bertanam padi tiga kali dalam satu tahun. Namun karena alasan ekonomi, penguasaan teknik budidaya dan resiko, para petani di DAS Catur tetap memilih untuk bertanam padi tiga kali dalam satu tahun. 
Kerusakan lahan di DAS Catur terjadi di lahan milik masyarakat seluas 1326,08 Ha, Perum Perhutani seluas 546,27 Ha dan PT Perkebunan Kandangan seluas 476,78 Ha. Penyebab kerusakan yaitu budidaya pertanian dan pembangunan permukiman di lahan curam. Kondisi ini dipengaruhi oleh tersedianya pasar komoditas pertanian seperti padi, jagung, singkong, coklat dan cengkeh sehingga mendorong masayarakat untuk membuka lahannya. Lahan dengan status hak milik, memberikan keleluasaan kepada pemilik untuk mengakses, mengelola dan memanfaatkan lahan yang dimilikinya (Hanna dan Munasinghe, 1995). Penyebab kerusakan di lahan Perum Perhutani yaitu penetapan sistem silvikultur (budidaya hutan) tebang habis permudaan buatan (THPB). Kondisi ini menyebabkan keterbukaan lahan, sehingga meningkatkan laju aliran permukaan dan erosi. Untuk mengurangi dampak penebangan sekaligus memberdayakan masyarakat sekitar hutan, Perum Perhutani bekerjasama dengan Lembaga Masyarakat Desa Hutan (LMDH) untuk melakukan agroforestri di lahan bekas tebangan. Pola tanam agroforestry ini dapat meningkatkan poduktivitas lahan dan penghasilan petani, mendukung ketahanan pangan serta mengurangi terjadinya aliran permukaan dan erosi (Khususiyah et al., 2009; Mayrowani dan Ashari, 2011; Junaidi 2013; Masnang et al., 2014). Namun berdasarkan wawancara dengan ketua kelompok tani hutan, kerena kurangnya pengawasan terdapat oknum anggota LMDH yang menjual-belikan lahan garapan. Penyebab kerusakan di lahan PT Perkebunan Kandangan yaitu budidaya pertanian lahan kering di lahan curam. Hasil wawancara dengan Yudi (Adm kebun), kegiatan tersebut dilakukan penggarap untuk memenuhi kebutuhannya selama perusahaan bangkrut. Perusahaan bangkrut sejak awal 1980 hingga tahun 2006, sehingga selama 20 tahun lebih HGU tersebut terlantar. Rehablitasi lahan baru dilakukan tahun 2006 seiring pergantian pemilik perusahaan. Rehabilitasi dilakukan dengan melibatkan penggarap untuk melakukan agroforestri serta pembuatan terasiring di lahan curam. Sebagaimana penelitian Maria dan Lestiana (2014) yang menyatakan bahwa pembuatan terasiring dan guludan di lahan pertanian mampu meningkatkan resapan air ke dalam tanah. Karena keterbatasan modal kegiatan rehabilitasi ini dilakukan secara bertahap.

Pemerintah mencegah dan mengendalikan terjadinya kerusakan lahan melalui penetapan fungsi kawasan. Penetapan fungsi suatu kawasan diatur melalui peraturan tentang penataan ruang dan kehutanan. Walaupun terdapat perbedaan terkait pejabat yang berwenang, proses serta penetapannya, seyogyanya dua peraturan ini bersinergi dan tidak saling tumpang-tindih karena telah dilakukan paduserasi TGHK dan RTRW Provinsi. Namun berdasarkan kajian di DAS Catur, terdapat tumpang tindih dalam penetapan fungsi kawasan hutan berdasarkan RTRW Kabupaten Madiun dan SK Menteri LHK. Terdapat lahan seluas 268,86 Ha yang berdasarkan RTRW ditetapkan sebagai kawasan hutan lindung tetapi berdasarkan SK Menteri LHK ditetapkan sebagai hutan produksi, begitu pula sebaliknya. Berdasarkan analisis kemampuan lahan, penetapan fungsi kawasan hutan berdasarkan RTRW lebih baik dibandingkan SK Menteri LHK. Penetapan fungsi kawasan hutan berdasarkan RTRW terdapat hutan produksi di lahan dengan kemiringan $>45 \%$ seluas 275, sedangkan berdasarkan SK Menteri LHK seluas 378,68. Kondisi ini dapat terjadi terjadi akibat perbedaan antar skala peta dan metode yang digunakan dalam penetapan fungsi kawasan.

RTRW Kabupaten Madiun seharusnya dipatuhi dan diimplementasikan seluruh aktor dalam penggunaan lahan di DAS Catur. Sedangkan implementasi SK Menteri LHK menjadi dasar terutama dalam pengelolaan hutan oleh Perum Perhutani. Namun kenyataannya terdapat penggunaan lahan yang tidak sesuai dengan RTRW seperti budidaya pertanian dan di kawasan resapan air dan sempadan sungai dengan luas mencapai 3.953,35 Ha. Ketidaksesuaian juga terjadi dalam implementasi SK Menteri LHK di dalam kawasan hutan seperti adanya semak belukar di hutan lindung dengan luas mencapai 382,85 Ha. Hal ini 
terjadi karena kurangnnya sosialisasi dan pengawasan dalam implementasi RTRW dan SK Menteri LHK instansi terkait.

\section{Pola Interaksi dalam Penggunaan Lahan di DAS Catur}

Uraian pada arena aksi menunjukkan belum adanya interaksi yang kurang baik antar aktor pengguna lahan di DAS Catur. Perbedaan penetapan fungsi kawasan antara RTRW Kabupaten Madiun dan SK Menteri Kehutanan menunjukkan lemahnya koordinasi di tingkat penetapan peraturan. Pelanggaran terhadap RTRW Kabupaten Madiun dan SK Menteri Kehutanan menunjukkan lemahnya koordinasi di tingkat pelaksanaan dan pengawasan peraturan. Adanya oknum anggota LMDH yang menjual-belikan lahan garapan menunjukkan lemahnya koordinasi di tingkat pelaksana penggunaan lahan. Begitu juga belum adanya komununikasi dan koordinasi antara aktor pengguna lahan dan aktor pemanfaat air yang terdampak penggunaan lahan. Hal ini merupakan bukti bahwa penyelenggaraan penggunaan lahan dilaksanakan secara parsial oleh masing-masing aktor. Oleh sebab itu, hingga saat ini belum program dan kegiatan yang berorientasi pada pencapaian tujuan bersama dalam pengelolaan DAS. Sebagai contoh, belum terealisasinya pembangunan Embung Kresek yang digagas Balai Besar Wilayah Sungai (BBWS) Bengawan Solo karena lokasinya berada di dalam kawasan hutan yang dikelola Perum Perhutani. Padalah Pemerintah Kabupaten Madiun juga sudah memberikan dukungan program tersebut dalam bentuk sosialisasi kepada masyarakat. Maka dari itu, dibutuhkan wadah untuk mengkoordinasikan berbagai kepentingan terkait penggunaan lahan di DAS Catur. Pemerintah telah membentuk wadah untuk mewujudkan koordinasi antar aktor dalam pengelolaan DAS, beberapa diantaranya adalah Musrenbang Kabupaten Madiun dan Forum Peduli DAS Solo

Musrenbang merupakan forum antar aktor dalam rangka menyusun rencana pembangunan (PRJP, RPJM dan RKP). Penyelenggaraan Musrenbang Kabupaten Madiun berpedoman pada UU Nomor 25 Tahun 2004 tentang Sistem Perencanaan Pembangunan Nasional. Penyelenggaraan Musrenbang dilakukan oleh Kepala Bappeda Kabupaten Madiun. Musrenbang dalam rangka penyusunan RPJPD dan RPJMD diikuti unsur-unsur pemerintahan dan melibatkan masyarakat sedangkan dalam penyusunan RKPD hanya diikuti unsur-unsur pemerintahan (SKPD dan DPRD Kabupaten Madiun). Dalam UU No 25/2004 juga tidak dijelaskan kriteria aktor yang perlu dilibatkan dalam Musrenbang. Berdasarkan hasil wawancara dengan beberapa aktor menyebutkan bahwa belum pernah ada pelibatan dalam musrenbang penyusunan rencana pembangunan Kabupaten Madiun. Kondisi ini menyebabkan belum terakomodirnya kepentingan aktor tersebut dalam rencana pembangunan Kabupaten Madiun.

Forum Koordinasi Pengelolaan DAS merupakan wadah koordinasi antar instansi penyelenggara pengelolaan DAS. Pembentukan Forum Koordinasi Pengelolaan DAS Solo yang selanjutnya disebut Forum Peduli DAS Solo berpedoman pada PP Nomor 37 Tahun 2012 tentang Pengelolaan DAS dan Peraturan Menteri Kehutanan Nomor 61 Tahun 2013 tentang Forum Koordinasi Pengelolaan DAS. Di Kabupaten Madiun, terdapat kepengurusan Forum Peduli DAS Solo yang terdiri dari unsur pemerintahan dan masyarakat (kelompok tani). Namun hingga saat ini Forum Peduli DAS Solo di Kabupaten Madiun belum memiliki program kerja karena belum mendapatkan anggaran walaupun dalan Permenhut Nomor 61/2013 dijelaskan bahwa pendanaan forum ini bersumber dari APBN, APBD maupun hibah yang tidak mengikat.

\section{Rumusan Pengembangan Kelembagaan Penggunaan Lahan di DAS Catur}

Rumusan pengembangan kelembagaan penggunaan lahan di DAS Catur lebih efektif apabila didasarkan atas permasalahan yang menyebabkan kerusakan DAS. Berdasarkan 
hasil analisis, permasalahan dalam penggunaan lahan di DAS Catur diantaranya:1) tumpang-tindih penetapan fungsi kawasan; 2) kurangnya sosialisasi dan pengawasan dalam pelaksanaan regulasi terkait penggunaan lahan; dan 3) belum optimalnya wadah koordinasi dalam mengakomodir kepentingan para aktor. Kondisi ini menyebabkan belum terciptanya keterpaduan tujuan, visi dan misi dalam penyelenggaraan penggunaan lahan di DAS Catur. Oleh sebab itu, strategi dalam pengembangan kelembagaan untuk meminimalisir permasalahan di DAS Catur dilakukan dengan mengatur penyelenggaraan koordinasi antar aktor. Artinya, adanya wadah koordinasi yang efektif merupakan prasyarat dalam meminimalisir permasalahan di DAS Catur.

Wadah koordinasi antar aktor terkait pengguna lahan di DAS Catur dilakukan melalui Musrenbang Kabupaten Madiun. Hal ini karena Musrenbang Kabupaten Madiun merupakan forum untuk menyusun rencana pembangunan yang pelaksanaanya dibiayai Anggaran Pendapatan dan Belanja Daerah (APBD) Kabupaten Madiun. Artinya, pengaturan penggunaan lahan dengan unit DAS mejadi paradigma bagi revisi maupun penyusunan RPJP, RPJM, RKP dan RTRW Kabupaten Madiun. Pengaturan penggunaan lahan dengan unit DAS membantu seluruh aktor memahami keterkaitan antara penggunaan lahan dan ketersediaan air di suatu DAS dalam rangka pembangunan di Kabupaten Madiun. Selain itu, hal ini dilakukan untuk menjamin penggunaan lahan secara berkelanjutan serta meningkatkan produktivitas dan kesejahteraan masyarakat, termasuk pendapatan daerah.

Pemerintah Kabupaten Madiun harus mengidentifikasi aktor pengguna lahan maupun aktor terdampaknya untuk dilibatkan dalam Musrenbang. Berdasarkan hasil penelitian, beberapa aktor pengguna lahan yang harus dilibatkan dalam Musrenbang diantaranya perwakilan Gapoktan, Perum Perhutani dan PT Perkebunan Kandangan serta BPKH Wilayah XI dan/atau BPDAS Solo (selaku unit pembantu KLHK dalam penetapan kawasan hutan dan pengelolaan DAS). Sedangkan aktor yang terdampak penggunaan lahan (pemanfaat air) yang harus dilibatkan diantaranya perwakilan Hippa, Perum Jasa Tirta I, Pabrik Gula Kanigoro dan Pagotan, PDAM Kabupaten Madiun, PLTA Golang dan Giringan serta BBWS Bengawan Solo (selaku unit pembantu Kementerian PU-PR dalam pengelolaan sumberdaya air).

Setiap aktor dapat menyampaikan program kerja dalam Musrenbang dengan tujuan 1) tercipta interaksi untuk mensinergiskan program antar aktor dan 2) menetapkan mekanisme pemberian insentif dan disinsentif antar aktor. Sinergitas program perlu ada untuk menciptakan rencana pembangunan yang berorientasi pada pencapaian tujuan bersama. Sedangkan insentif dan disinsentif perlu ada untuk memberikan dorongan dan batasan dalam penyelenggaraan pembangunan (termasuk penggunaan lahan) di Kabupaten Madiun. Beberapa hasil yang harus dicapai dalam Musrenbang Kabupaten Madiun diantaranya: 1) perencanaan pembangunan Kabupaten Madiun; 2) pengorganisasian rencana pembangunan Kabupaten Madiun; 3) mekanisme pelaksanaan rencana pembangunan Kabupaten Madiun; dan 4) mekanisme pengawasan dan evaluasi terhadap pelaksanaan pembangunan Kabupaten Madiun. Dengan demikian, pembangunan Kabupaten Madiun (termasuk DAS Catur) mengacu pada satu perencanaan yang dilaksanakan secara bersama oleh seluruh aktor sesuai kewenangannya serta dikerangkakan pada pencapaian tujuan bersama, yaitu pembangunan berkelanjutan.

\section{KESIMPULAN}

Penyelenggaraan penggunaan lahan di DAS Catur seyogyanya dikerangkakan dalam sistem pembangunan Kabupaten Madiun dengam melibatkan seluruh aktor terkait. Hal ini dilakukan supaya terjadi sinergitas program dan kegiatan seluruh aktor sehingga tercipta penggunaan lahan yang produktif dan berkelanjutan. Namun kenyataannya, terdapat 
berbagai permasalahan kelembagaan penggunaan lahan di DAS Catur yang meliputi 1) tumpang-tindih regulasi penetapan fungsi kawasan; 2) kurangnya sosialisasi dan pengawasan dalam pelaksanaan regulasi; serta 3) belum efektifnya wadah koordinasi dalam mengakomodir kepentingan seluruh aktor.

Permasalahan kelembagaan penggunaan lahan di DAS Catur dapat diminimalisir melalui koordinasi yang baik antar aktor yang diwadahi dalam Musrenbang yang diselenggarakan Bappeda Kabupaten Madiun. Mursrenbang Kabupaten Madiun dipilih sebagai wadah koordinasi karena hasil Musrenbang adalah rencana pembangunan yang pelaksanaanya dibiayai APBD Kabupaten Madiun. Hal ini juga merupakan upaya untuk menjadikan pengaturan penggunaan lahan dengan unit DAS mejadi paradigma bagi revisi maupun penyusunan rencana pembangunan dan RTRW Kabupaten Madiun. Keterlibatan seluruh aktor dalam Musrenbang mampu menciptakan interaksi untuk mensinergiskan program antar aktor serta menetapkan mekanisme pemberian insentif dan disinsentif yang dituangkan dalam rencana pembangunan Kabupaten Madiun. Dengan demikian, rencana pembangunan Kabupaten Madiun dapat dikerangkakan pada pencapaian tujuan bersama, yaitu pembangunan berkelanjutan.

Pemerintah Kabupaten Madiun perlu mengidentifikasi dan meningkatkan partisipasi seluruh aktor dalam Musrenbang. Tata cara penyusunan perencanaan pembangunan daerah dan pelaksanaan mursrenbang perlu dituangkan dalam bentuk Perda Kabupaten Madiun untuk memberikan payung hukum terutama terkait pelibatan instansi nonpemerintahan. Pengelolaan SDA (termasuk pengelolaan DAS) seharusnya dikerangkakan dalam kelembagaan sistem pembangunan.

\section{DAFTAR PUSTAKA}

Arsyad S. 2010. Konservasi Tanah dan Air.Edisi ke-2. Bogor (ID): IPB Pr.

Asdak C. 2010. Hidrologi dan Pengelolaan Daerah Aliran Sungai. Yogyakarta (ID): UGM Pr.

[Bappeda] Badan Perencanaan Pembangunan Daerah Kabupaten Madiun. 2015. Kondisi Demografis Kabupaten Madiun Tahun 2015. Madiun (ID): Bappeda Kabupaten Madiun

[BPBD] Badan Penanggulangan Bencana Daerah Kabupaten Madiun. 2015. Rekap Bencana Kabupaten Madiun Tahun 2015. Madiun (ID): BPBD Kabupaten Madiun

[BPSDA] Balai Pengelolaan Sumberdaya Air Provinsi Jawa Timur. 2016. Data Pemantauan Debit Sungai Catur Tahun 2011-2015. Madiun (ID): BPSDA Provinsi Jawa Timur.

[Ditjen PDAS-HL] Pengendalian Daerah Aliran Sungai dan Hutan Lindung Kementerian Lingkungan Hidup dan Kehutanan. 2015. Rencana Strategis Direktorat Jenderal Pengendalian Daerah Aliran Sungai dan Hutan Lindung Tahun 2015-2019. Jakarta (ID): Ditjen PDAS-HL KLHK

Halim F. 2014. Pengaruh Hubungan Tata Guna Lahan Dengan Debit Banjir Pada Daerah Aliran Sungai Malalayang. Jurnal Ilmiah Media Engineering, Vol 4 (1), 45-54.

Hanna S, Munasinghe M. 1995. An Introduction to Property Rights and The Environment. Washington (US): The World Bank

Harjianto M, Sinukaban N, Tarigan SD, Haridjaja O. 2016. Analisis Kemampuan Lahan untuk Arahan Penggunaan Lahan di DAS Lawo, Sulawesi Selatan. Jurnal Penelitian Kehutanan Wallacea. Vol 5 (1): 11

Junaidi E. 2013. Peranan Penerapan Agroforestry Terhadap Hasil Air Daerah Aliran Sungai (DAS) Cisadane. Jurnal Penelitian Agroforestry. Volume 1 (1): 41-53.

Kartodihardjo H, Murtilaksono K, Sudadi U. 2004. Institusi Pengelolaan Daerah Aliran Sungai: Konsep dan Pengantar Analisis Kebijakan. Bogor (ID): Fakultas Kehutanan Institur Pertanian Bogor.

[Kemenhut] Kementerian Kehutanan. 2009. Instruksi Menteri Kehutanan Nomor: INS.3/Menhut-II/2009 Tentang Penetapan Wilayah Kerja BPDAS. Jakarta (ID): Kemenhut

Khususiyah N, Suyanto, Buana Y. 2009. Pengelolaan Hutan Bersama Masyarakat (PHBM): Pembelajaran Keberhasilan dan Kegagalan Program. Di dalam: Rahayu S, editor. Policy Analysis Unit, 2009 November; Bogor, Indonesia. Bogor (ID): ICRAF Tersedia pada: http://www.worldagroforestry.org/sea/Publications/files/leaflet/LE0168-10.pdf 
Kusrini, Suharyadi, Hardoyo S R. 2011. Perubahan Penggunaan Lahan dan Faktor yang Mempengaruhinya Di Kecamatan Gunungpati Kota Semarang.Majalah Geografi Indonesia. Volume 25 (1): 25-40.

Masnang A, Sinukaban N, Sudarsono, Ginting N. 2014. Kajian Tingkat Aliran Permukaan dan Erosi pada Berbagai Penggunaan Lahan di Sub DAS Jenneberang Hulu. Jurnal Agroteknos. Volume 4 (1): 32-37.

Maria R, Lestiana H. 2013. Banjir: Pengaruh Penggunaan Lahan Terhadap Fungsi Konservasi Air Tanah di Sub DAS Cikapundung. Jurnal RISET Geologi dan Pertambangan. Volume 24 (85): 77-89.

Mayrowani H, Ashari. 2011. Pengembangan Agroforestry untuk Mendukung Ketahanan Pangan dan Pemberdayaan Petani Sekitar Hutan. Forum Penelitian Agro Ekonomi. Volume 29 (2): 83-98.

Murtilaksono K. 2013. Penyelarasan Implementasi Pengelolaan Daerah Aliran Sungai di Indonesia. Bogor (ID): Orasi Ilmiah Guru Besar Tetap Ilmu Tanah, Fakultas Pertania, IPB

Nursidah, Nugroho B, Darusman D, Rusdiana O, Rasyid Y. 2012. Pengembangan Institusi untuk Membangun Aksi Kolektif Lokal dalam Pengelolaan Hutan Kawasan Lindung SWP DAS Arau, Sumatera Barat. Jurnal Managemen Hutan Tropika. Vol XVIII (1): 18-30. 10.7226/jtfm.18.1.18

Ostrom E. 2005. Understanding Institutional Diversity. New Jersey (US): Princeton University Press

Ostrom E, Hess C. 2007. Private and Common Property Right. Di dalam: editor. Workshop in Political Theory and Policy Analysis, Indiana University. Tersedia pada: http://ssrn.com/abstract=1304699

Ostrom E. 2010. Institutional Analysis and Development: Elements of The Framework in Historical Perspective. Di dalam: Crothers C, editor. Historical Developments And Theoretical Approaches in Sosiology/Social Theory, 2010 Mei 10; Auckland, New Zealand. Auckland (NZ): UNESCO-EOLSS. Tersedia pada: http://www.eolss.net/sample-chapters/c04/e6-99a-34.pdf

Permatasari R, Arwin, Natakusuma D K. 2017. Pengaruh Perubahan Penggunaan Lahan terhadap Rejim Hidrologi DAS (Studi Kasus: DAS Komering). Jurnal Teoritis dan Terapan Bidang Rekayasa Sipil. Volume 24 (1): 91-98.

Rosyidie A. 2013. Banjir: Fakta dan Dampaknya, serta Pengaruh dari Perubahan Guna Lahan. Jurnal Perencanaan Wilayah dan Kota. Volume 24 (3): 241-249.

Sudirman S, Irham, Hartono S, Maas A. 2010. Analisis Faktor Penyebab dan Dampak Perubahan Penggunaan Lahan Pertanian Pinggiran Kota Yogyakarta. Jurnal Sosial Ekonomi Pertanian. Vol 4 (1): 47-59

Saida, Jusoff K, Islan M, Haris A, Nuraeni. 2013. Evaluation of Land Capability for Agriculture in the Upstream of Jeneberang Watershed. American-Eurasian Journal of Agricultural and Environmental Science. Vol 13 (8): 1029-1033

Sunarti, Sinukaban N, Sanim B, Tarigan SD. 2008. Konversi Hutan Menjadi Lahan Usahatani Karet dan Kelapa Sawit serta Pengaruhnya terhadap Aliran Permukaan dan Erosi Tanah di DAS Batang Pelepat. Jurnal Tanah Trop. Vol 13 (3): 253-260

Verbist B, Putra AE, Budidarsono S. 2004. Penyebab Alih Guna Lahan dan Akibatnya terhadap Fungsi Daerah Aliran Sungai (DAS) pada Lanskap Agroforestri Berbasis Kopi di Sumatera. Agrivita. Vol 26 (1): 29-38. 0126-0537 